\title{
Ways of introducing judgments and sources of information in a popular science text devoted to astronomy
}

\author{
Svetlana Bylkova ${ }^{*}$, Margarita Finko ${ }^{2}$, and Igor Kudryashov ${ }^{3}$ \\ ${ }^{1}$ Don State Technical University, 1, Gagarin Sq., Rostov-on-Don, 344003, Russia \\ ${ }^{2}$ Don State Technical University, 1, Gagarin Sq., Rostov-on-Don, 344003, Russia \\ ${ }^{3}$ Southern Federal University, 105 / 42, Bolshaya Sadovaya Str., Rostov-on-Don, 344006, Russia
}

\begin{abstract}
The journalist's personality acts as an intermediary between scientists and non-professional readers, whose knowledge of astronomy is limited, and the created popular science texts are a kind of communicative platform for voicing judgments. In this regard, journalists not only supplement the reader's knowledge in an accessible form, but also open access to the voices of representatives of the scientific and astronomical community, relying on such means as direct and indirect speech, which reveal different degrees of frequency in the first paragraph of the text and in the subsequent narrating. To systematize the actual data indicating the explicit labeling of the source of information in a popular science message, the most frequent language signals that are used by journalists in order to introduce a other voice into the text (predicates that introduce direct or indirect speech) were analyzed. As a result, models and indicators of their frequency were identified, which provided an opportunity to trace the trends in voicing the expert astronomers' opinions in a popular scientific text. It is established that the distribution of direct and indirect speech with explicit marking of the source of information in the first paragraph of the popular science text is not homogeneous. In this text segment, indirect speech is the most frequent, which allows the journalist to focus the reader's attention on an unbiased vision of a scientific event.
\end{abstract}

\section{Introduction}

Texts published in popular science journals provide up-to-date information about achievements, discoveries and inventions, and embody the direct or indirect exchange of specialized knowledge between the journalist and the target audience, probably in order to smooth out the epistemological gap that is found between the scientific communities and the general readership. The popularization of the discourse of scientific communities is objectified by the journalist in such a way as to construct specialized knowledge in general terms, to integrate this knowledge into the presuppositions of the reader, who, in fact, is not an expert in the field under discussion. The journalist uses a number of communication

\footnotetext{
* Corresponding author: svetbyl17592@rambler.ru
} 
strategies of popular science explanation of effective knowledge in order to create flexible associations in the reader's mind between the existing information and the new information. In this regard, the scientific discourse, interpreted in popular terms, is structured as a didactically predetermined text that focuses the reader's attention on the journalistic point of view on the issues under discussion [1-3].

Actual knowledge, initially formulated in the disciplinary context, is subsequently reproduced in a different communicative context, the essential factor of interpretation of which is not a representative of the relevant scientific community, but a mass potential reader. In other words, within the framework of popular publications, scientific discourse is forwarded to the addressee-a non-specialist, which, in turn, determines the popularized nature of the presentation of disciplinary knowledge. The popularization of scientific knowledge in magazine texts is embodied in a variety of genres that combine oral and written registers of speech, the reduction of information that is not relevant to the mass audience, the modification of the language design of the actual content [4-6]. Representatives of various scientific communities focus on the theoretical definition of the immanent value of disciplinary (technological) achievements, for the mass reader, the practical value of a discovery or invention for everyday life is constructive. The popularization of scientific knowledge in periodicals is interpreted as a kind of social process, involving the use of a number of discursive and semiotic practices for the wide dissemination of information about the methodological views and concepts of research scientists [7-9]. This process is characterized not so much by the creating specific textual structures and constructions, but by the features of the recreated communicative context, which is formed by such factors as the popularizer journalist, the publication of sources of relevant information, the mass address, the relevance of new information for nonprofessional knowledge of the surrounding reality [10-12]. Combining the educational and entertainment functions of the media, periodicals make an active contribution to the production and dissemination of new disciplinary knowledge, the point of view on the functions of science in modern society and the activities of scientists belonging to various professional communities. As a result, scientists and journalists realize a common illocutionary goal associated with unobtrusive and orderly informing the mass addressee about the state of a particular scientific discipline at the current stage of development.

At the moment, the problem of popularization of scientific achievements in the media is a stable subject of research in both general and private linguistics [13-14]. It seems that the increased interest of linguists in this problem is primarily associated with the ability to systematically trace the relationship between scientific academic discourse and the communicative contexts of the publication of new disciplinary knowledge, taking into account the global and local level of the text. Popular science texts can be qualified as a reliable source of linguistic ideas about the regularities of the functioning of everyday and professionally-oriented language. The coupling of the discourse of contemporary science and the popularization of scientific knowledge and concepts is interpreted in this study as a linearly unfolding continuum, within which, depending on the addressee factor, two registers of information disclosure are consistently differentiated.

Scientific discourse formulates the results of cognition of reality in terms of concepts, theories and hypotheses, and is intended for a specialized addressee. A constructive role is played by the terminological language, which modifies the everyday vocabulary, forming semantically compact and, if possible, unambiguous units. The reader is called upon to be an expert in the field under study in order to be multi-dimensionally aware of the scientific discourse: scientists publish information for a selected addressee based on the so-called «scientific metaphor», a metaphorical semantic space that includes the entire history of studying a particular problem [15-16]. When modeling popular science discourse, a journalist usually projects a new context in order to frame relevant information from a 
different explanatory perspective. A strong author's principle is introduced into the discourse, since the popularizing style involves focusing the reader's attention on the direct collision of the investigating human-being with the mysterious regularities and mechanisms of the inner and outer reality. In scientific discourse, on the contrary, the emphasis is on concepts and research techniques, through which the scientist comprehends a certain segment of reality, using specific syntactic constructions and lexicon, reflecting the conceptual structure of disciplinary knowledge.

\section{Materials and methods}

The linguistic concepts developed under the auspices of the anthropocentric paradigm emphasize the importance of language research in a wide variety of contexts and types of texts [17-19]. At the same time, various concepts of the discursive analysis dealing with the contextual functioning of the language, predetermined by a specific text embodiment, begins to play the most constructive role. The revealed illustrative text material provides linguists-researchers with contexts of the use of language constructions, which, in turn, creates the basis for significant results in the framework of discursive analysis.

The research is based on such concepts and theories that focus on such important parameters of interpersonal interaction in various types of text and discourse as:

- dialogic predestination of the message [20];

- dialogic projection of verbatim / non-verbatim citation [21];

- the constructive nature of the argumentation when expressing an opinion [22-23].

As the research material, publications in the Russian magazine «Nebosvod»/ «Sky» are used, the target audience of which is fans of astronomy. Using the continuous sampling method, we analyzed 49 texts (out of 12 issues of the journal for 2017), which cover the problems of contemporary astronomy, current achievements and discoveries made by research astronomers in a popular scientific way. The choice of these texts is dictated by the fact that their authors (journalists), covering the current state of the science of astronomy, as a rule, explicitly disclose the source of relevant information.

The card file containing the total number of analyzed messages, in which the source of information is explicitly marked, was 283 examples. Relying on the methods of contextual analysis of mass media messages, identifying the source of relevant information, statistical calculation of empirical data, we try to trace how journalists, interpreting the achievements and discoveries in modern astronomy in popular scientific terms, provide access to the voices of experts in the text, act as intermediaries between expert astronomers and readers, lovers of astronomy. In this regard, journalists not only recreate information for nonspecialists in the field of astronomy, but also incorporate the scientists' voices into the narrative space of a popular science text, using them as a means of expressing an argumentative strategy.

\section{Results}

The ideas about the localizing the source of information as part of a popular scientific judgment with the structure of indirect and direct speech in terms of such parameter as the first paragraph of the publication / the subsequent presentation of information about an astronomical discovery are systematized.

The article defines the pragmatic features of the thematic and rematic functions of the linguistic means that nominate researchers-astronomers and their professional communities in journalistic judgments, which are based on the model of indirect and direct speech. It is 
established that these nominations function in the popular science text as references to the source of information of journalistic reports.

\section{Discussion}

In the studied popular science texts, the source of information, which is the justification of the journalist's judgments about the achievements and discoveries in the field of contemporary astronomy, is the opinion of an authoritative expert. In turn, this opinion serves as an argument for the position that the journalist takes in the text. Journalistic labeling of the point of view expressed by expert astronomers is carried out in the following three ways.

1. The most verbatim quotation of the judgment of an astronomer-specialist in the form of direct speech:

(1) «Rukovoditel’ komandy Roberto Majolini iz Kembridzhskogo universiteta govorit: "Nashi rezul'taty... odnoznachno pokazyvajut, chto zvezdy rozhdajutsja vnutri jetih potokov". Gruppa sdelala prjamoe bezoshibochnoe obnaruzhenie molodoj zvezdnoj populjacii v ottoke»; "Team leader Roberto Maiolini of the University of Cambridge says, "Our results... clearly show that stars are born inside these streams." The team made a direct error-free detection of a young stellar population in the outflow» [24].

The journalist does not reproduce the specialist's full judgment in the origin of stars, but only those segments of it that do not contain terminology and clearly reflect the problems discussed in the popular science text.

2. Selective quoting of the expert astronomer's judgment in the form of indirect speech:

(2) «Professor Mike Brown schitaet, chto Jerida stolknulas's drugim objektom pojasa Kojpera $v$ samom nachale svoej istorii. Imenno stolknovenie privelo ejo $v$ bystroe vrashhenie i izmenilo sharoobraznuju formu na udlinennuju»; "Professor Mike Brown considers that Eris collided with another Kuiper Belt object early in its history. It was the collision that brought it into a rapid rotation and changed its spherical shape to an elongated one» [25].

The journalist adapts a well-known astronomer's judgment in terms that are accessible to the reader's perception, and in linguistic terms forms it as his own statement.

3. Integration of an expert astronomer's judgment into a journalistic narrative that lacks the predicates of speaking or mental activity characteristic of direct and indirect speech:

(3) «Konkretnyh dokazatel'stv, kotorye mogli by podtverdit' sushhestvovanie zagadochnoj planety, uchenye poka ne obnaruzhili, za iskljucheniem stranno dvizhushhihsja asteroidov $i$ rjada karlikovyh planet v pojase Kojpera. Po predvaritel'nym ocenkam uchenyh period vrashhenija "planety $H$ " vokrug Solnca-odin oborot v techenie 15 tysjach let, chto tak zhe poka ne daet ponjat', gde ona nahoditsja»; (3) "Scientists have not yet found any concrete evidence that could confirm the existence of the mysterious planet, with the exception of strangely moving asteroids and a number of dwarf planets in the Kuiper Belt. According to preliminary estimates of scientists, the rotation period of "planet X" around the Sun is one revolution for 15 thousand years, which also does not yet make it clear where it is» [26].

The journalist voices experimental data previously published in scientific publications and hypothetical conclusions of scientists about the existence and rotation period of «planet $\mathrm{X} »$ in order to formalize personal judgments about the activities of astronomers in the field of studying the Solar System. The source of information is lexicalized in these judgments based on nouns concrete evidence (not obtained), and preliminary estimates of scientists. As part of our research, we do not take into account this type of popular science representation of the astronomers' point of view, since in such a context, language structures are used not to project the judgments of authoritative persons, but for the purpose 
of argumentatively expanding the semantic position taken by a journalist in an explanatory text. In this regard, our pragmatic analysis includes the first two types of introduction of expert astronomers' judgments, which serve as relevant sources of information for journalistic conclusions in popular scientific texts.

The problem of distribution of each of the studied types of disclosure of the source of information collected in our card file requires a more detailed analysis. According to the data given in Table 1, the total number of identified contexts for the use of direct and indirect speech is comparable both in the first paragraph of a popular science publication and in its subsequent narrative.

Table 1. Distribution and frequency of information sources in popular science judgment.

\begin{tabular}{|c|c|c|c|}
\hline $\begin{array}{c}\text { Type of disclosing } \\
\text { the source of } \\
\text { information }\end{array}$ & $\begin{array}{c}\text { The first paragraph of } \\
\text { the scientific popular } \\
\text { article }\end{array}$ & $\begin{array}{c}\text { The subsequent } \\
\text { narrative in the article }\end{array}$ & Total quantity \\
\hline Indirect speech & $21(22.3 \%)$ & $73(77.7 \%)$ & $94(100 \%)$ \\
\hline Direct speech & $7(8.6 \%)$ & $74(91.4 \%)$ & $81(100 \%)$ \\
\hline
\end{tabular}

A comparative analysis of the use of direct and indirect speech reveals the fact that when marking the source of relevant information, journalists resort to verbatim quoting the judgments of astronomers-experts, as a rule, not in the first paragraph of a popular scientific publication, but in the subsequent narrative. For selective citation, on the contrary, the initial paragraph is the most frequent position.

When designing a source of relevant information through indirect speech, journalists do not so much provide the reader with access to the discursive voice of astronomersresearchers, as they adapt their judgments in accordance with the pragmatic goals pursued in the text, namely, they translate the essence of the astronomical discovery in terms accessible to a non-professional target audience. The contextual parameter of the original message takes on the pragmatic meaning that the journalist gives it. $\mathrm{Cf}$.:

(4) «... v rabote avtory otmechajut, chto naibol'shej intensivnosti processy zvezdoobrazovanija dostigajut $v$ central'nom uzle sistemy SDC13, gde zaregistrirovany naibolee vysokaja skorost' dvizhenija gaza i formirovanie naibolee massivnyh jader zvezd, kotorye v budushhem stanut odnimi iz samyh massivnyh zvezd nashej Galaktiki»; "... in the paper, the authors note that the most intense star formation processes are achieved in the central node of the SDC13 system, where the highest gas velocity and the formation of the most massive star cores are recorded, which in the future will become one of the most massive stars in our Galaxy» [27].

Without going into the technical characteristics of the current formation of the celestial body, the journalist provides the reader with basic information about the intensive process of star formation, based on common concepts and language expressions. As we have already noted, the incorrect quoting of the judgments of astronomers in the function of marking the source of information is more frequent not in the first paragraph of the text, but in the subsequent narrative. For a more detailed analysis of the empirical data we obtained, we identified the frequency of indirect speech for every 10 contexts of the total number of explicitly expressed sources of information. This standard measurement makes it possible to trace the uniformity of the distribution of this type of information sources in the card file we have collected. 94 contexts of marking the source of information through indirect speech were identified. From this it follows that the frequency of this source is 3.95 uses for every 10 contexts of publication of the source of information in the collected file. In the course of further analysis, it was found that in the first paragraph of the popular science text, the frequency of indirect speech in the pragmatic function we are considering is 0.88 uses for every 10 contexts in which the actual source of information is marked; in the subsequent presentation of the popular science text, this proportion is 3.05 uses, again, for 
every 10 contexts. According to the obtained empirical data, the considered popular science texts reveal a different concentration of indirect speech as a source of information for journalistic judgments, depending on whether this syntactic structure is used in the first paragraph or in the subsequent coverage of astronomical problems.

Table 2. The concentration of indirect speech as a marker of the source of information in popular science texts.

\begin{tabular}{|c|c|c|c|c|}
\hline \multicolumn{1}{|c|}{} & $\begin{array}{c}\text { Number of } \\
\text { references to the } \\
\text { source of } \\
\text { information } \\
\text { Card file }\end{array}$ & $\begin{array}{c}\text { Number of } \\
\text { contexts with } \\
\text { indirect speech } \\
\text { paragraph of the } \\
\text { scientific popular } \\
\text { article }\end{array}$ & $\begin{array}{c}\text { Frequency for } \\
\text { every 10 } \\
\text { references to the } \\
\text { source of } \\
\text { information }\end{array}$ \\
\cline { 2 - 5 } & $\begin{array}{c}\text { The subsequent } \\
\text { narrative in the } \\
\text { article }\end{array}$ & 58 & 21 & 0.88 \\
\cline { 2 - 6 } & Total & 225 & 73 & 3.05 \\
\hline
\end{tabular}

The number of uses of indirect speech in the first paragraph of the scientific popular publication is significantly lower than in the subsequent narrative. It seems that this trend can be explained as follows. The first paragraph takes a strong semantic position in the popular science text: the journalist constructs the context for the subsequent coverage of astronomical discoveries or achievements, introduces personal comments to the discussed issues, and then gives the right to voice their position to astronomers-experts.

In the card file we have collected, we also differentiate between different models of the representation of the source of information, in which a particular sequence of the source marker and the reproducible judgments of research astronomers is detected. In particular, the contexts in which the source of information functions as an initial component of the judgment are distinguished. In this case, the journalist emphasizes the constructive role of representatives of the scientific astronomical community in the process of cognition of outer space, and the judgment is based on the model of a complex sentence with an explanatory subordinate part. Cf.:

(5) "Issledovateli soobshhajut $v$ novoj rabote, chto zvezda TRAPPIST-1 dovol'no staraja - ejo vozrast sostavljaet ot 5.4 do 9.8 milliarda let»; "The researchers report in a new paper that the star TRAPPIST-1 is quite old - its age ranges from 5.4 to 9.8 billion years» [28].

The names of the astronomers-researchers and their scientific project are indicated at the textual initial part, and therefore the subject of the main part of the complex sentence (as well as the one of the subordinate clause) performs the function of the theme, the new information about the subject of the subordinate clause realizes the function of the rheme in the statement. An indication of the source of information, which is represented by authoritative scientists, can be qualified as an argument in favor of the reliability of the subsequent judgment. The reproduced opinion, which belongs to authoritative research astronomers, is of an assertive nature, which, in turn, is projected by the semantics of the predicate that introduces this opinion (to report). In other words, there is a correlative tie between the lexical meaning of the verbal predicate that marks the indirect speech and the semantics of the subsequent statement as a particular speech act. Such a semantic onesidedness of the judgments of scientists and predicates, which introduce these judgments in the form of indirect speech, is characteristic of the following illustrative examples (cf. 
predicates of speaking or mental activity to speak / say, mark, emphasize, consider, which introduce assertive speech acts that reflect the point of view of astronomers on a certain state of affairs in the empirical study of celestial bodies).

In popular science explanatory texts published in the journal «Nebosvod», there are also contexts in which an indication of the source precedes the new information about the discussed cosmic phenomenon. In this case, the information source directly occupies the final position of the message. Cf.:

(6) «Podobnye vzryvnye volny, rasprostranjajushhiesja na ogromnye rasstojanija, voobshhe dovol'no redki, schitajut predstaviteli gruppy specialistov, vozglavljaemoj ispanskim uchenym Iisusom Maisom Apel'janisom iz Andalusskogo astrofizicheskogo instituta»; "Such explosive waves propagating over huge distances are generally quite rare, consider the representatives of a group of specialists led by the Spanish scientist Jesus Maiz Apelianis from the Andalusian Astrophysical Institute» [29].

The reader's attention is focused on detailing the extraordinary, hitherto unexplored characteristics of active cosmic processes, and the source of information is indicated additionally, as a secondary component of the judgment. Again, such a distribution of the new information and the source of its receipt is dictated by the author's pragmatic goals, related to maintaining the interest of the target audience in the unknown phenomena of physical magnetism that are periodically observed on the solar disk.

Our file also contains a number of illustrative examples in which the source of information, marked by the subject and predicate of speaking or mental activity, is wedged between the components of the judgment that implement indirect speech. Cf.:

(7) «U celi, kak nebezosnovatel'no govorjat avtory proekta, zond manevriruet takim obrazom, chto parus prevrashhaetsja v linzu Frenelja, fokusirujushhuju signal zonda $v$ napravlenii Zemli»; "At the target, as the authors of the project rightly say, the probe maneuvers in such a way that the sail turns into a Fresnel lens, focusing the probe's signal in the direction of the Earth» [30].

In such a context, the reader perceives the new information and simultaneously holds its source in long-term memory. In other words, the author of a popular science text attaches constructive significance both to the achievement of the astronomical order and to the scientists to whom this achievement belongs.

To determine the frequency of the selected three models that record the introduction of a source of information when activating indirect speech as part of journalistic judgments of a popular science nature, we turned mainly to the analysis of the first paragraphs of publications. As we have already noted, in this text segment, 21 such contexts are identified, of which 12 record the publication of the source of information in the initial position of judgments. At the same time, nominations, references to scientists-astronomers who made a particular discovery (subjects of the main part of a complex sentence when entering indirect speech) serve as a thematic component. As a result, the structure of indirect speech, which in a popularized form expresses the opinion of astronomers about the studied celestial body, takes a strong semantic position in the text of the publication, which, in turn, becomes an incentive for increased reader attention. In 6 contexts of popular science judgments with the structure of indirect speech, the source of information is activated in the middle position, which focuses the reader's attention on the importance of entering the names of astronomer researchers-along with their achievements - into the long-term memory. According to our observations, nominative phrases, which are references to researchers-astronomers and / or their professional communities, implement a rhematic function in these contexts. In other words, information about scientists is entered into the text work for the first time. A similar function is performed in the initial segment of the text and nominative means of publishing the source of information in the final position of the judgment, i.e. after indirect speech (3 identified contexts). 
The introduction of indirect speech turns out to be a fairly frequent journalistic procedure for marking the source of information in a mass-media text devoted to popular science coverage of the problems of modern astronomy and astronautics (94 judgments out of 283 analyzed contexts). As evidenced by the actual data collected for this study, this function is no less frequently used by the authors of popular science texts and direct speech, providing the reader with access to the authoritative voices of researchers-astronomers. In the context of making judgments in the form of direct speech, the reports of scientists are not transformed or simplified; the reader's attention is focused on the personal contribution of certain representatives of the scientific astronomical community to the development of relevant issues. Cf.:

(8) "Chem bol'she my uznaem o OTS44, tem bol'she on stanovitsja pohozh na moloduju zvezdu. No ego massa nastol'ko mala, chto nashi vyvody protivorechat obshheprinjatym modeljam", - skazala Amelija Bajo, vedushhij avtor issledovanija iz universiteta Val'paraiso (Chili)»; " "The more we learn about OTS44, the more it becomes like a young star. But its mass is so small that our findings contradict conventional models", said Amelia Baio, lead author of the study from the University of Valparaiso (Chile)» [31].

The subjective and personal interpretation of the empirical parameters of a new planetary object, carried out by a leading researcher who is a source of information for the journalistic report, is marked with the personal and possessive pronoun of the 1 -st person plural (the astronomer expresses an opinion on behalf of the entire astronomical community functioning in the University of Valparaiso), indicating the contradictory nature of the results achieved. As evidenced by the statistical data systematized in Table 3, direct speech shows a stable tendency to frequency of functioning not in the first paragraph of a popular scientific text, but in the subsequent covering of information. This trend can be explained by the fact that in the first paragraph of the publication, the journalist outlines the initial scientific problems, which are further explained to the reader in generally accessible terms, and states the general state of affairs in astronomy in the aspect of the topic under discussion. As a result, in the initial text segment, the author of a popular science publication, as a rule, does not verbatim voice the voices of professional experts, resorting to this method of marking the opinions of astronomers and the source of relevant information in the subsequent narrative. It is in the course of further covering of the scientific and astronomical event that the journalist reveals additional details, develops the ideas that were stated in the first paragraph, argues these ideas, including relying on direct quoting of the astronomer researchers' point of view and an explicit indication of the source of relevant information. The reader is provided with a popular interpretation of the phenomenon under discussion, involving particular examples and more accurate empirical data.

Table 3. The concentration of direct speech as a marker of the source of information in popular science texts.

\begin{tabular}{|c|c|c|c|c|}
\hline & & $\begin{array}{l}\text { Number of } \\
\text { references to the } \\
\text { source of } \\
\text { information }\end{array}$ & $\begin{array}{l}\text { Number of } \\
\text { contexts with } \\
\text { direct speech }\end{array}$ & $\begin{array}{l}\text { Frequency for } \\
\text { every } 10 \text { references } \\
\text { to the source of } \\
\text { information }\end{array}$ \\
\hline \multirow{3}{*}{ Card file } & $\begin{array}{c}\text { The first paragraph } \\
\text { of the scientific } \\
\text { popular article }\end{array}$ & 58 & 7 & 0.12 \\
\hline & $\begin{array}{c}\text { The subsequent } \\
\text { narrative in the } \\
\text { article }\end{array}$ & 225 & 74 & 3.2 \\
\hline & Total & 283 & 81 & 3.32 \\
\hline
\end{tabular}


Analyzing the obtained statistical data we come to the conclusion that there is a clear difference between the tendencies in using the direct speech in the first paragraph of a popular scientific publication and in the subsequent narrative $(0.12$ and 3.2 cases for every 10 contexts of use). At the same time, we note the absence of any uniformity of the models of constructions with direct speech in the first paragraph of the text work. The variability of these models is determined by the different order of the verbatim reproduction of the message (the researchers-astronomers' judgment) and the author's words (the subject which is the source of information in the message). Despite the fact that the frequency of models in the first paragraph of a popular science publication is low, we were able to identify relevant models of direct speech in this text segment. In particular, our file contains 4 examples of the use of judgments with the structure of direct speech, in which the author's words as an explicit indication of the source of information function as thematic components, i.e. propositional content already known to the reader from the previous context and re-identifying the subjects voicing a new judgment. Cf.:

(9) «V to zhe samoe vremja Mauk otmetil: “ $V$... nashih dannyh est' nameki na to, chto $s$ rostom plotnosti jenergii generiruemyh poljarnyh sijanij process stanovitsja nestabil'nym, $i v$ dejstvie vstupaet inoj process uskorenija. Odnako jeta gipoteza trebuet dal'nejshej proverki"》; "At the same time, Mauk noted: "In ... our data, there are hints that as the energy density of the generated auroras increases, the process becomes unstable, and a different acceleration process takes effect. However, this hypothesis requires further testing"》 [32].

As in the judgment (8), the scientist-astronomer scientist-astronomer's point of view, literally voiced by the journalist, reflects the hypothetical, exhaustively unverified empirical nature of the concept being developed, its novelty and theoretical significance. Such a perspective of presenting current knowledge to the reader implies an explicit reference to the source of information, since this information is a scientific achievement of a particular professional community of astronomers.

The card file contains the only example in which an astronomer's verbatim message is broken by an explicit reference to the source of the information. Cf.:

(10) «"Gamma-luchi ispuskajutsja jelektronami, uskorjajushhimisja do ochen' vysokih skorostej $v$ chudovishhnom magnitnom pole "jekstremala" (takie skorosti poka eshhe nedostizhimy dazhe na samyh moshhnyh zemnyh uskoriteljah), - podcherknul F. Arojan.Odnako gde imenno $i$ za schet kakogo konkretnogo mehanizma proishodit uskorenie jetih jelektronov, do sih por nejasno"»; (10) " "Gamma rays are emitted by electrons accelerating to very high speeds in the monstrous magnetic field of the "extreme" (such speeds are still unattainable even on the most powerful Earth accelerators)", stressed F. Aroyan. "However, it is still unclear exactly where and by what specific mechanism these electrons are accelerated" " [33].

The researcher's judgments reflect the state of affairs in the Russian astronomical science, which has not yet received an exhaustive multidimensional analysis. A nominative phrase expressed by a proper name, which is an explicit reference to the source of information, performs the function of the topic in the utterance. The journalist reindividualizes the subject, a representative of the astronomical scientific community, who has made a significant contribution to the study of gamma rays, and at the same time publishes the basic provisions of the concept under discussion (i.e., new information). In other words, the author of a popular science text makes an attempt to establish flexible associative links between the topic and the subject of the message, to lay this association in the long-term memory of the reader. In the analyzed context, the break in direct speech with the author's words focuses the reader's attention on the equal status of known and new information (cf. with fragment (9), in which the primary role for the reader's perception is acquired by the message's rhema, i.e., the researcher-astronomer's judgment). 
In a popular science text, when introducing messages with the structure of direct speech, the source of information can receive additional detail. In this case, the journalist focuses on the ways of voicing judgments by representatives of the same scientific community, who jointly solve current problems of empirical modeling of celestial bodies, which is reflected in the use of several introduced predicates with different semantics, which are preceded by the subject, an explicit source of information. Cf:

(11) "Sejchas astronomy opisyvajut period vrashhenija chernyh dyr, kotoryj "po predvaritel'nym raschetam sostavljaet okolo 30 tysjach let”. Oni takzhe nadejutsja v budushhem najti i drugie podobnye pary chernyh dyr: "oni dolzhny vstrechat'sja dovol'no chasto v galaktikah", - otmechaet G. Tejlor»; (11) "Now astronomers describe the rotation period of black holes, which "according to preliminary calculations is about 30 thousand years." They also hope to find other similar pairs of black holes in the future: "they should occur quite often in galaxies", notes G. Taylor» [34].

The astronomers / they / G. Taylor nominations express the representatives of the University of New Mexico who conduct observations of supermassive black holes and are the sources of information for this journalistic report. The predicates used in these subjects reflect the nature of the information received by the author of a popular science text, which is a consequence of the description, hopes and statements of astronomers of the declared scientific community. In the first sentence, the journalist resorts to direct quoting, but from the context of the mass media narrative, the reader reveals that the author of the voiced opinion is an astronomer, whose judgment is verbatim given below (i.e., G. Taylor).

\section{Conclusion}

Within the framework of this article, the starting point of the research is the theoretical position, according to which reports on discoveries and achievements in the field of astronomy appear as a frequency phenomenon, covered in specialized popular scientific texts. As a result, a pragmatic analysis of the source of information and ensuring access to the voices of astronomer researchers in a journalistic report is an urgent problem.

A striking characteristic of the popular science text is its multidimensional dialogical predestination. This type of text contains numerous segments of dialogues that are implemented in the communicative space of scientific and astronomical communities, and appear as a frequent means of publishing the opinions of researchers and the source of information for these opinions. Creating popular science texts, journalists pass the quoted messages through the prism of the pursued communication strategies, which are primarily associated with the argumentation of judgments about discoveries and achievements in the field of modern astronomy. When extracted from the original scientific context, the quoted messages become an integral component of the popular text.

Universal communication processes are based on the potencies of language, primarily related to the implementation of the message function. In the theory of language, numerous concepts are created, in which the specifics of the integration of linguistic events into the speech acts of messages are reconstructed; it is indicated that the language design of messages shows a flexible dependence on the context of the unfolded communication, including on the communicative processes that took place before. During the replay, the pre-voiced information is adapted as effectively as possible to the current communication situation by potentially truncating it, adding descriptive or evaluative components. In this regard, we can talk about various models of pointing to the source of information, which are often used in a popular science text, linguistic mechanisms of reasoned persuasion of the readership as a culturally relevant form of popular science communication. 


\section{References}

1. R. S. Ngula, Brno Studies in English, 43(2), 45-56 (2017), doi: 10.5817/BSE2017-2-1

2. R. Gronda, G. Turbanti, European Journal of Pragmatism and American Philosophy, 9(2), 1-24 (2017)

3. A. F. Roman, R, M. Roman, Procedia - Social and Behavioral Sciences, 163, 214-219 (2014), doi: 10.1016/j.sbspro.2014.12.309

4. S. H. Johansen, Contrastive Pragmatics, 2(1), 81-105 (2020), doi: https://doi.org/10.1163/26660393-12340006

5. G. Pounds, Discourse Studies, 12, 106-137 (2010), doi: 10.1177/1461445609346777

6. J. Parkinson, International Journal of Corpus Linguistics, 18(2), 199-228 (2013), doi:10.1075/ijcl.18.2.02par

7. J. Alireza, International Journal of Applied Linguistics, 22(1), 23-41 (2012), doi:10.1111/j.1473-4192.2011.00291.x

8. I. Shchemeleva, ESP Today, 7(1), 24-43 (2019), https://doi.org/10.18485/esptoday.2019.7.1.2

9. K. Davidse, L. Vandelanotte, Journal of Pragmatics, 43(1), 236-250 (2011), doi: 10.1016/j.pragma.2010.07.022

10. L. Ilinska, O. Ivanova, Z. Senko, Procedia - Social and Behavioral Sciences, 236, 248258 (2016), doi: 10.1016/j.sbspro.2016.12.020

11. B. Bellés-Fortuňo, New Insight into the Analysis of Medical Discourse, Academic and Popular Settings, 65-88 (2016), doi: 10.21832/9781783096268-005

12. O.A. Pilkington, Text\&Talk, 38(6), 753-773 (2018), doi: http://doi.org/10.1515/text2018-0022

13. S. Moirand, S. Reboul-Touré, M. P. Ribeiro, Bakhtiniana: Revista de Estudos do Discurso, 11(2), 145-170 (2016), dx.doi.org/10.1590/2176-45732387

14. S. V. Bylkova, I. A. Kudryashov, Social Sciences, 6, 167-178 (2017)

15. V. I. Karasik, E. A. Kitanina, Questions of Cognitive Linguistics, 2, 64-72 (2020), doi: 10.20916/1812-3228-2017-4-80-89

16. S. V. Bylkova, Herald of Russian New University, Series «Human being in contemporary world», 1, 58-62 (2020), doi: 10.25586/RNU.V925X.20.01.P.058

17. I. V. Kovtunenko, S. V. Bylkova, I. A. Kudryashov, E. A. Korman, Scientific Dialogue, 2, 79-94 (2021), doi: 10.24244/2227-1295-2021-2-79-94

18. G. D. Sknar, I. A. Kudryashov, RUDN Journal of Russian and Foreign Languages Research and Teaching, 15(1), 51-65 (2017), doi: 10.22362/2313-2264-2017-15-1-5165

19. I. V. Kovtunenko, S. V. Bylkova, V. A. Borisenko, N. A. Minakova, V. I. Rogacheva, XLINGUA, 11(2), 95-105 (2018), doi: 10.18355/XL.2018.11.02.08

20. S. V. Bylkova, E. P. Chubova, V. V. Kolmakova, Contemporary Research of Social Problems (Electronic Scientific Journal), 9(3), 74-96 (2018), doi: 10.12731/22187405-2018-3-74-96

21. P. Vallejos, British Journal of Education, Society and Behavioural Science, 12(2), 1-10 (2016), doi: 10.9734/BJESBS/2016/20634

22. A. Smirnova, Text\&Talk, 32(2), 235-253 (2012), doi:10.1515/text-2012-0012

23. D.Trine, F. Kjersti, Text\&Talk, 34(4), 401-420 (2014), doi:10.1515/text-2014-0009 
24. M. Rybakov, Nebosvod, 5, 4-9 (2017)

25. A. Kozlovskyj, Nebosvod, 1, 3-10 (2017)

26. M. Rybakov, Nebosvod, 8, 4-11 (2017)

27. M. Rybakov, Nebosvod, 9, 8-17 (2017)

28. M. Rybakov, Nebosvod, 11, 6-12 (2017)

29. M. Borisov, Nebosvod, 11, 23-28 (2017)

30. D. Mamontov, Nebosvod, 2, 14-19 (2017)

31. M. Rybakov, Nebosvod, 7, 6-10 (2017)

32. M. Borisov, Nebosvod, 3, 4-8 (2017)

33. M. Rybakov, Nebosvod, 9, 6-10 (2017)

34. M. Rybakov, Nebosvod, 4, 5-8 (2017) 